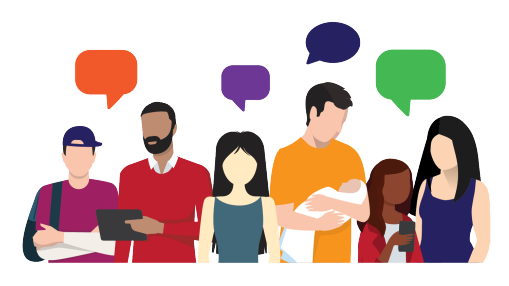

\title{
Youth Survey
}

Luxembourg

\section{Diversity, National Identity, and Political Participation among Young People in Luxembourg}

Alessandro Procopio Lea Schomaker Robin Samuel 


\section{Acknowledgements:}

The authors sincerely thank the following individuals and institutions for their valuable comments and support:

Conny Roob from the Direction générale du Secteur de la Jeunesse;

All the adolescents and young adults who tested the questionnaire or participated in the survey.

The analyses and interpretations presented in this report are those of the authors, and do not necessarily represent the views of the people who have commented or of the institutions that have provided financial or other support.

\section{Suggested citation:}

Procopio, Alessandro; Schomaker, Lea; Samuel, Robin (2021): Diversity, National Identity, and Political Participation among Young People in Luxembourg. University of Luxembourg; Esch-sur-Alzette. DOI: https://doi.org/10.31219/osf.io/uzeka 


\section{Contents}

1 National identity as a concept 6

2 Political participation as an established subject in (social science) research $\quad 8$

3 The relationship between political interest and the different aspects of national $\begin{array}{ll}\text { identity } & 13\end{array}$

4 The role of migration background 16

5 Discussion $\quad 18$

6 Outlook - New ways of youth political engagement 18

$\begin{array}{llr}7 & \text { Annex } & 20\end{array}$

\section{List of Tables}

1 Univariate Frequency Distributions of the Elements of National Identity . . . . 20

2 Univariate Frequency Distributions of the Elements of National Identity by Migration Background . . . . . . . . . . . . . . . . . . . . . 21

3 Absolute and Percentage Frequency of the means of Political Participation . . . 23

4 Univariate Distribution of the Interest in Politics . . . . . . . . . . . . . . . . . 23

5 Absolute and Percentage Frequency of Political Interest relative to Migration Background . . . . . . . . . . . . . . . . . . . 24

6 Logistic Regression Model of elements of National Identity on SES (individual) Without Interaction Effects . . . . . . . . . . . . . . . . . 25

7 Logistic Regression Model of elements of National Identity on SES (individual) With Interaction Effects . . . . . . . . . . . . . . . . . . . 25

8 Logistic Regression Model of elements of National Identity on SES (own family) Without Interaction Effects . . . . . . . . . . . . . . . . . . 26

9 Logistic Regression Model of elements of National Identity on SES (own family) With Interaction Effects . . . . . . . . . . . . . . . 27

\section{List of Figures}

1 (High) Importance of National Identity aspects, in percent (YSL 2019) . . . . .

2 National identity aspects considered (very) important, by migration background, in percent $($ YSL 2019) . . . . . . . . . . . . . . . . . . . 7

3 Predicted probabilities for assessing ius soli and ius sanguinis as important by time spent in Luxembourg . . . . . . . . . . . . . . . . . . . . . 8 8

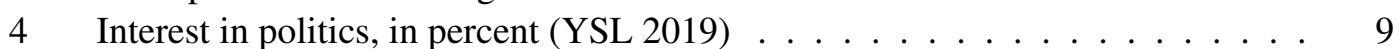

5 Political interest by migration background, in percent (YSL 2019) . . . . . . . 10

6 Level of political interest by gender (Panel A) and by age group (Panel B). YSL $2019 \ldots \ldots \ldots \ldots 11$

7 Types of political actions done in the past, in percent (YSL 2019) . . . . . . . . 11

8 Political actions done in the past by migration background (YSL 2019) . . . . . 12 
9 Cross-tabulation of levels of interest in politics (in columns) and importance of elements of national identity (in rows). Percentages are computed by column. Luxembourg, 2019 (YSL 2019) . . . . . . . . . . . . . . . . . . . . . 14

10 Probability of answering 'Important' versus 'Not Important' to the items of national identity by levels of political interest (YSL 2019). . . . . . . . . . . 15

11 Probability of answering 'Important' versus 'Not Important' to the items of national identity by levels of political interest (YSL 2019). . . . . . . . . . . . 17 


\begin{abstract}
Luxembourg is known for its cultural and national diversity. Approximately $48 \%$ of the population is foreigners live in Luxembourg. For 15-29-year-olds, this share was approximately $42 \%$ in 2019 and 2020. Furthermore, approximately 185,000 foreign workers commute to Luxembourg daily. Considering this, Luxembourg is an interesting case for investigating national identity and political participation of a diverse society (STATEC 2020a, STATEC 2020b, STATEC 2021). Especially, as the biographies of young people in Luxembourg are becoming increasingly complex (e.g., mixed national parents; highly skilled expatriates), it is worth looking into different aspects and valuations of national identity and political participation of youth in Luxembourg (Amétépé and Hartmann-Hirsch, 2011). In this policy report, we look into the aspects of national identity and how young people living in Luxembourg define a 'real Luxembourger' using the

Youth Survey Luxembourg (2019) data (Sozio et al., 2020). This will give us the opportunity to investigate what aspects of identity (e.g. Luxembourgish ancestry; the time spent living in Luxembourg) matter for young people to feel part of Luxembourgish society and how these change across different social backgrounds and demographics. The discourse about the interrelations of political participation and youth brings forward the dominant narrative of a disengaging and passive youth. Here, we also investigate these statements in the Luxembourgish context. We analyse the level of interest in politics across young people in Luxembourg and their means of political participation. Finally, we especially investigated the relationship between aspects of national identity, and political interest and engagement of young people in Luxembourg.
\end{abstract}




\section{National identity as a concept}

There are numerous ways to define and analyse national identity, and what is considered pivotal for the categorisation of national identity across state-of-the-art research, particularly in political science and migration studies (Canan and Simon, 2018; Dumbrava and Bauböck, 2015a; McLaren, 2017; Murdock, 2012; Umaña-Taylor et al., 2020; Vink and de Groot, 2010). However, two well-established concepts are ius soli and ius sanguinis. These represent the most common concepts based on which citizenship is granted. These are also considered central aspects of national identity and the feeling of belonging. Ius soli describes, on the one hand, the concept of granting citizenship based on the place of birth. Ius sanguinis, on the other hand, grants citizenship based on bloodlines or ancestry. Current research concedes that these concepts are somewhat outdated and argue that aspects of a more civic or participatory approach should be considered (Dumbrava and Bauböck, 2015a,1; McLaren, 2017). Here, we therefore investigate not only the aspects of ius soli and ius sanguinis but also aspects of social and cultural integration, such as having lived in Luxembourg for long, speaking Luxembourgish well, and identifying oneself with Luxembourg. Figure 1 shows what young people in Luxembourg consider (very) important to be 'a real Luxembourger'.

Figure 1: (High) Importance of National Identity aspects, in percent (YSL 2019)

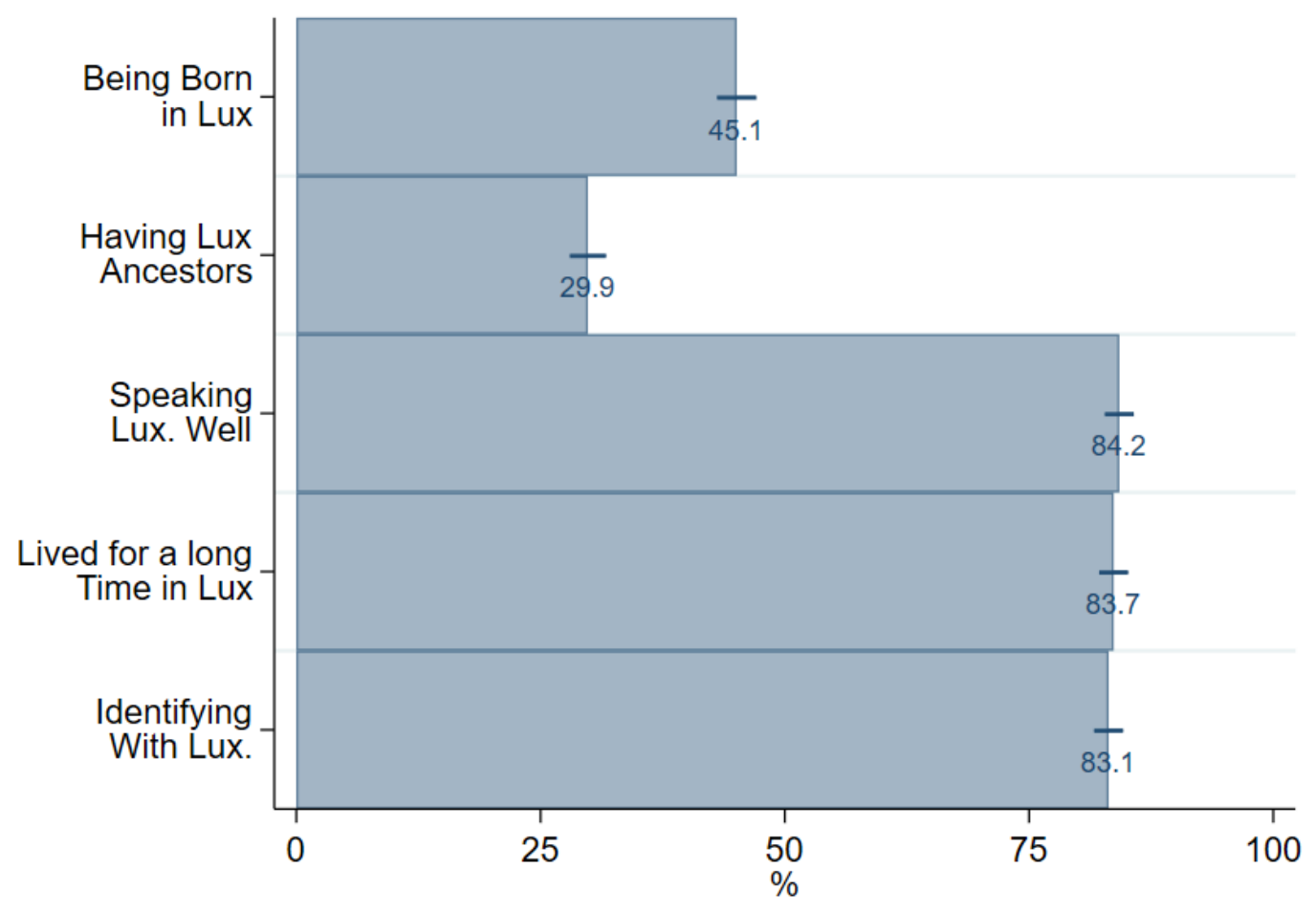

$\mathrm{N}=2506,2504,2508,2506,2505$

Clearly, the three socio-cultural aspects of national identity are (very) important to most young people (82-85 \%) in Luxembourg compared to the aspects of being born in Luxembourg (ius soli) and having Luxembourgish ancestors (ius sanguinis), which only $46 \%$ and $30 \%$, respectively, consider (very) important. According to the European Values Study 2008 (European Values Study, 2016), the overall population of Luxembourg (18+) deems the ius soli (41\%) and ius sanguinis (26\%), even less important than young people. The same applies to the item 
'Having lived in Luxembourg for a long time' (71\%). This study also shows that, overall, in Luxembourg, birthplace and ancestry are considered less important by 18+ year-olds for one's national identity compared to the overall population of Germany, Belgium, and France. Figure 2 shows the national identity aspects aggregated by migration background. We find statistically significant differences for several of the five national identity aspects (European Values Study, 2016). Self-immigrated respondents deem being born in Luxembourg (ius soli) as less important than respondents with no or second-generation immigration background. Regarding ius sanguinis, second-generation immigrants consider it less important compared to other respondents.

Figure 2: National identity aspects considered (very) important, by migration background, in percent (YSL 2019)

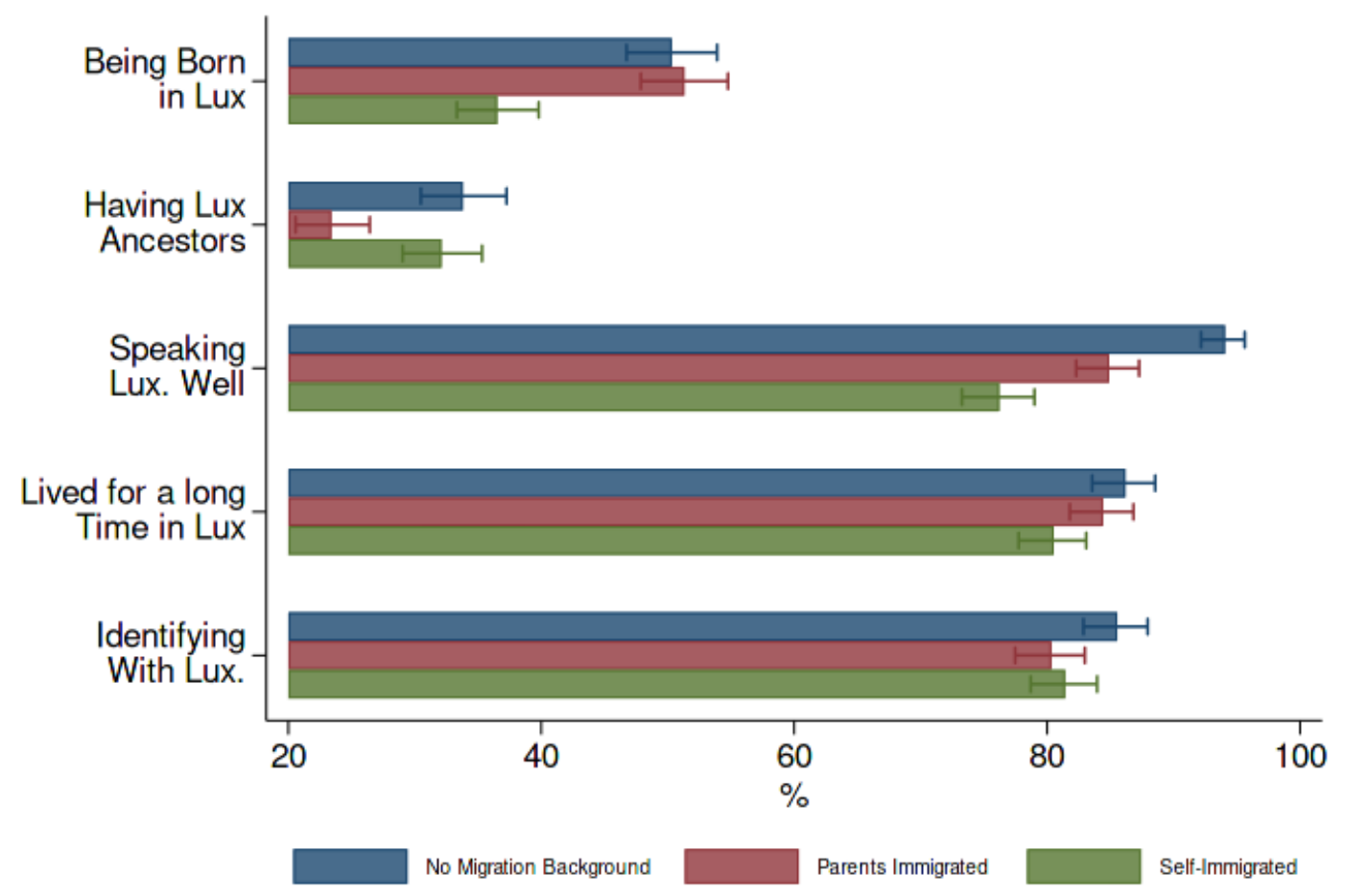

$\mathrm{N}=2506,2504,2508,2506,2505$

Regarding the Luxembourgish language, $94 \%$ of young people without a migration background consider this as a (very) important aspect to be considered 'a real Luxembourger' and show statistically significantly higher results than both first- and second-generation immigrants ( $85 \%$ and $76 \%$, respectively). While the aspects 'Having lived in Luxembourg for a long time' and 'identifying oneself with Luxembourg' show high numbers, there are no significant differences by migration status. Next, using a multivariate model, we investigate the effects of not only migration background but also gender, age, and socioeconomic background (SES) on national identity (see Annex). Here, we find a statistically significant negative effect of SES (defined as the perceived wealth of one's family) on the national identity item of 'being born in Luxembourg' (see Annex). That is, the higher the perceived family wealth, the lower the probability of respondents assessing being born in Luxembourg as important. However, there are no significant results for interaction effects between migration background and perceived family wealth. This means that the migration background is not subtly moderating the effect of SES on the assessment of 'being born in Luxembourg'. 
Figure 3: Predicted probabilities for assessing ius soli and ius sanguinis as important by time spent in Luxembourg
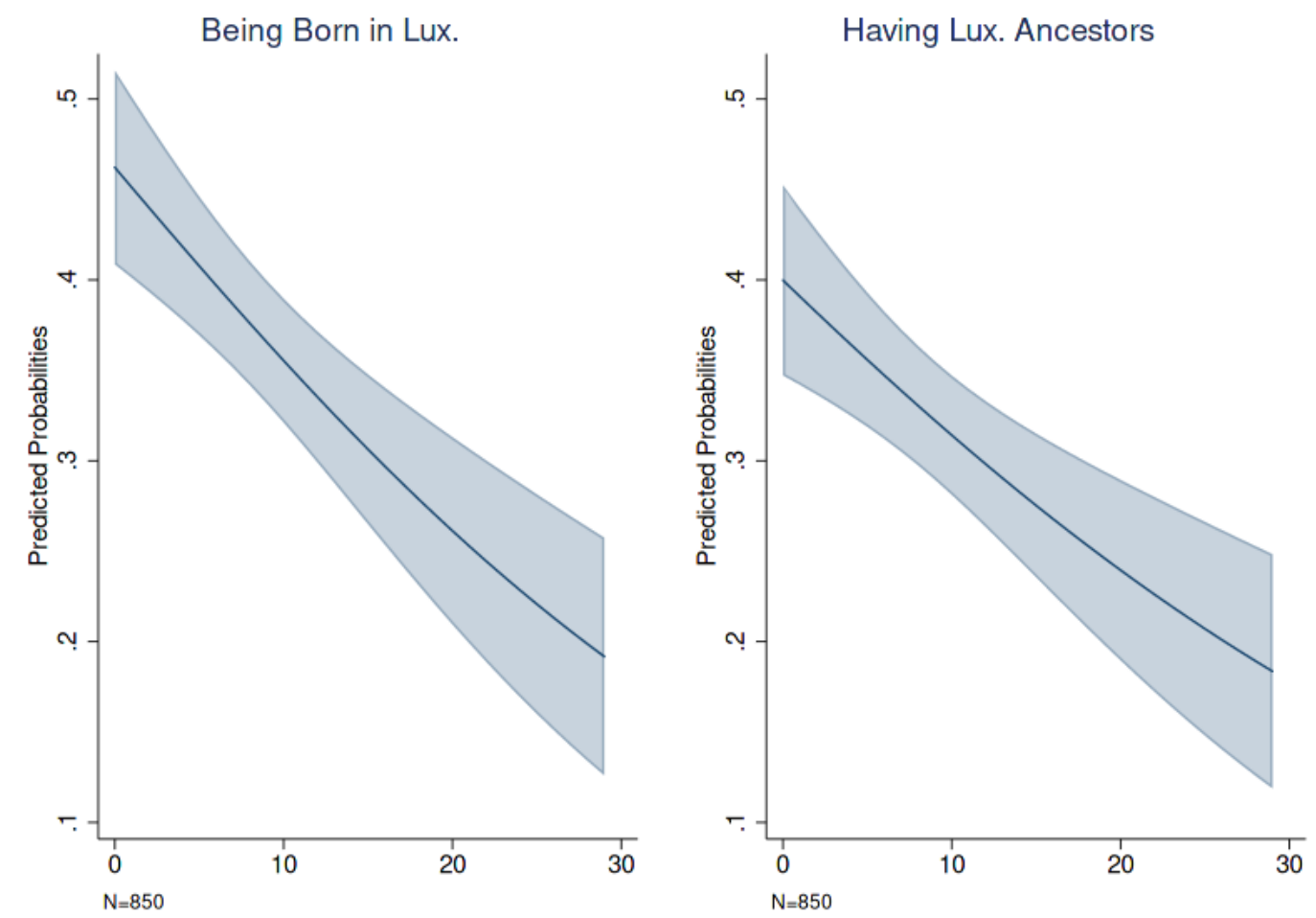

When defining SES as the perceived wealth of one's own life, we only find statistically significant results for the national identity item of 'Identifying with Luxembourg'. As before, we do not find proof for the interaction of one's own perceived wealth with migration background (for more details, see Annex). Regarding the time spent in Luxembourg, we find significant results for the national identity items of 'being born in Luxembourg' and 'having Luxembourgish ancestors'. Figure 3 shows that the longer the respondents have lived in Luxembourg, the lower the probability of assessing these items as important.

\section{Political participation as an established subject in (social science) research}

Studies have broadly discussed the effect of socioeconomic and sociodemographic backgrounds on political participation. Recent research shows that a central problem in investigating these relationships are conceptual confusions around political participation, and social, cultural, and monetary capital. It is often unclear what these concepts entail and how to best operationalise them (Brady et al., 1995; Ekman and Amnå, 2012; Gallego, 2007; Schlozman et al., 1994; Skocpol and Fiorina, 1999; Villano and Bertocchi, 2014; Zani and Barrett, 2012). Some authors argue that the inadequate operationalisation of political participation misses the diverse and unconventional forms of political participation that youth engage in (Kitanova, 2020). Ekman and Amnå (2012) state that there is 'the tendency in the literature to focus on manifest activities and neglecting the "latent” forms of political participation' (Ekman and Amnå, 2012:284). Here, we will therefore look at both conventional and unconventional forms of political participation. This 
is especially important since not all young people residing in Luxembourg, particularly those under the age of 18, have the right to vote in Luxembourg. Regardless of age, youth is the defining transition period into adulthood, and thus, central to the individual development of young people as citizens. Therefore, we must consider a range of political participation forms. For the Luxembourgish context, the Youth Report Luxembourg (Ministère de l'Éducation nationale, de l'Enfance et de la Jeunesse and Université du Luxembourg, 2015) investigates the engagement types of young people at different levels and in different forms of participation. This analysis is based on the 'Civic Voluntarism Model' (Brady et al., 1995). This model proposes that the participation of young people is strongly influenced by individually available resources such as money, education, skills, and time as well as the individual motivation, aspiration, and the immediate social network. The Youth Report Luxembourg 2015 shows the importance of the educational background of youth, their immigration status or nationality, their overall SES, age, and gender for political participation, among other factors. In summary, the aspects behind the political participation of Luxembourgish youths are diverse and eclectic. Here, we analyse the effects of migration background on the political interest and activity of young people in Luxembourg as - considering this policy paper's focus on diversity and national identities - this is the central factor. Figure 4 shows that the majority of young people in Luxembourg report having low- to medium-level interest in politics, while only around $20 \%$ report to be extremely or very interested in politics.

Figure 4: Interest in politics, in percent (YSL 2019)

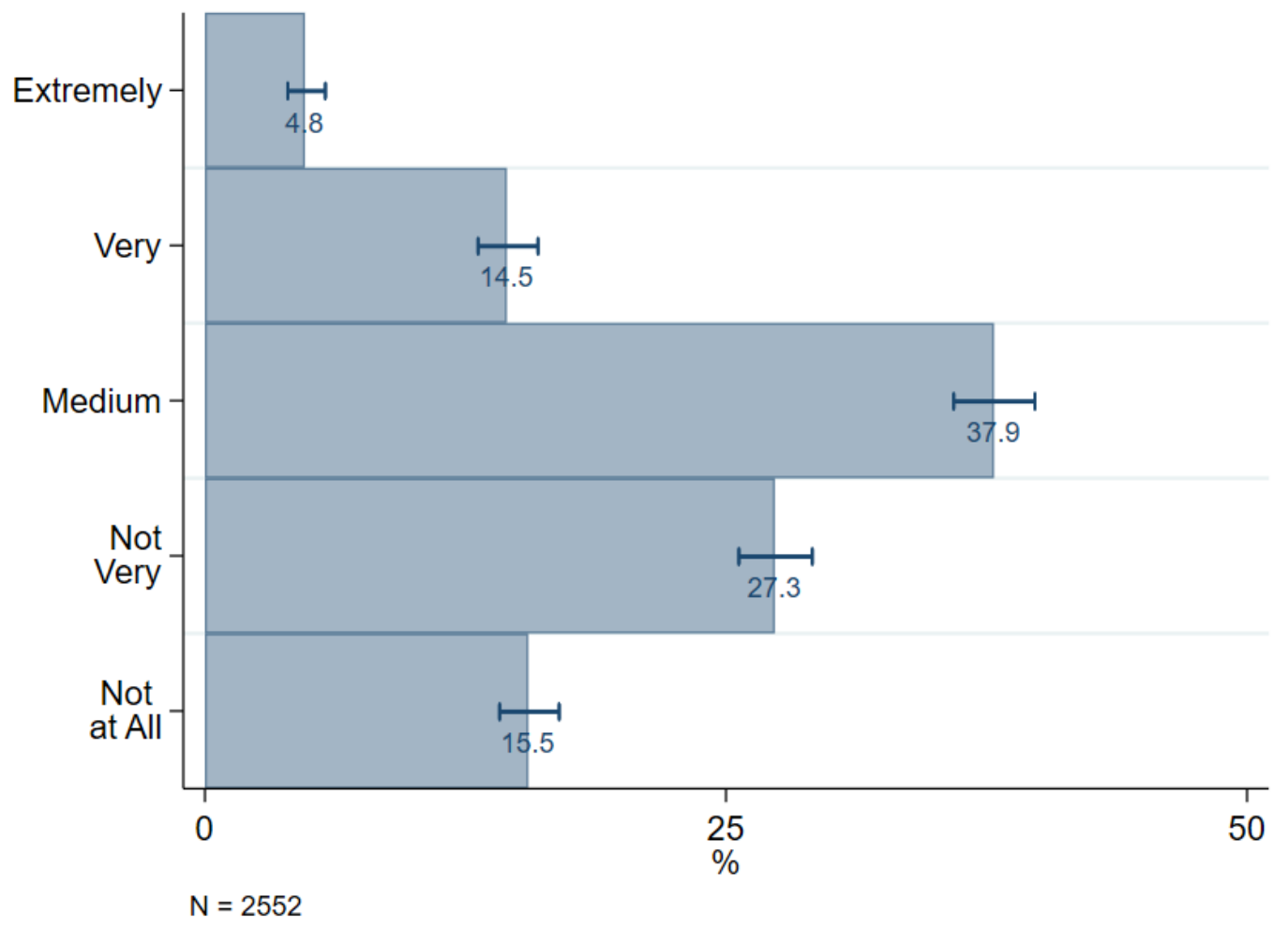

Aggregated by migration status (see Figure 5), we find that the immigration status or timing of immigration play a role in the level of political interest of young people in Luxembourg. A higher proportion of self-immigrated respondents are extremely/very interested in politics (20\%) compared to second-generation immigrants (14\%). The number of respondents with no migra- 
tion background who are extremely/very interested in politics (21\%) is only slightly higher than that of the self-immigrated group. However, most young people report not being interested in politics, with self-immigrated respondents making up the largest share (46\%), closely followed by second-generation immigrants (45\%) and respondents with no migration background (40\%).

Figure 5: Political interest by migration background, in percent (YSL 2019)

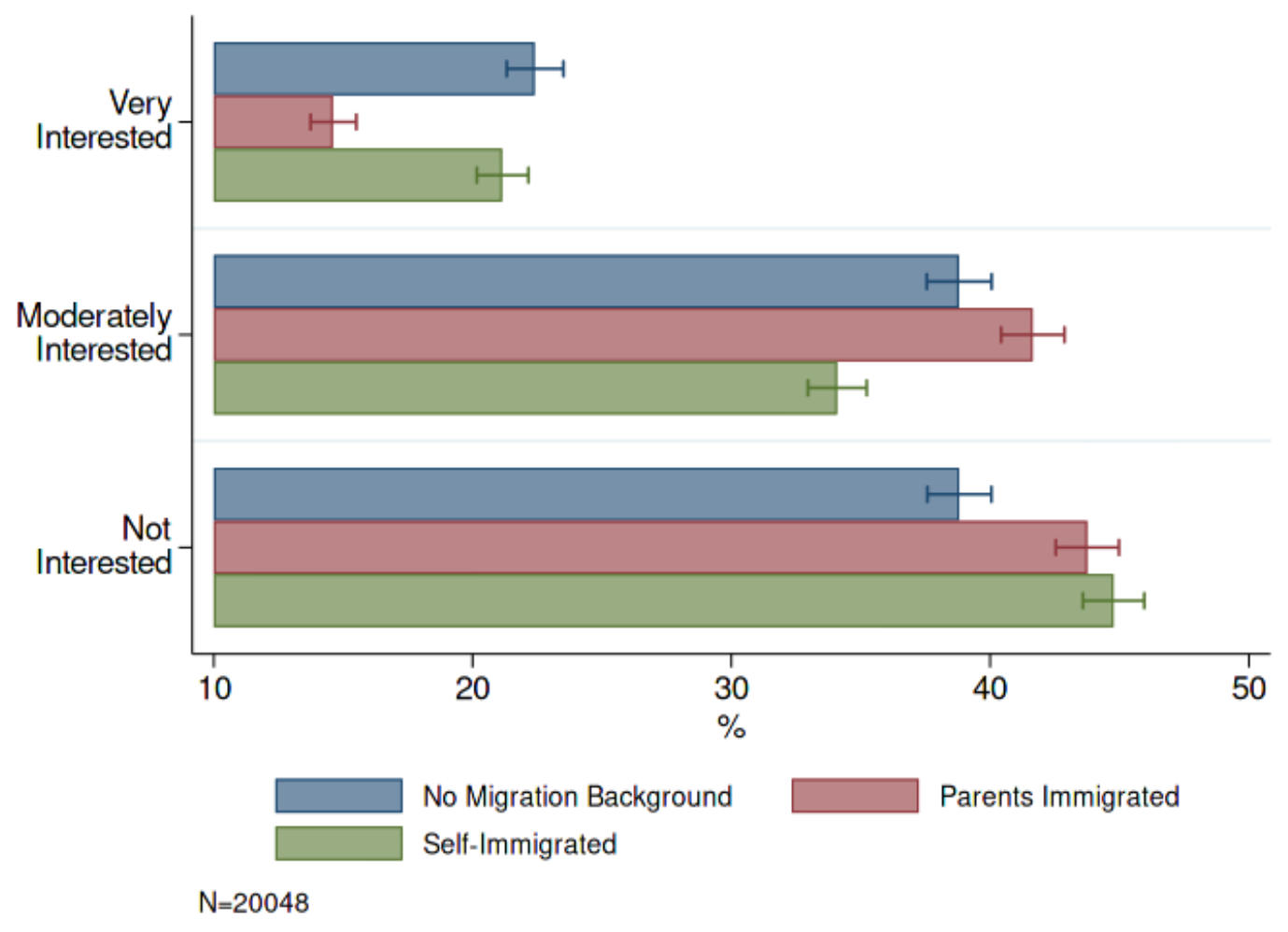

Figure 6a shows that there are gender differences in the level of interest in politics. For the moderate interest level, the difference between male and female respondents is not significant. More male respondents $(25 \%)$ report having a high level of interest in politics than female respondents $(13 \%)$. The opposite is true for no interest in politics (37\% males versus $49 \%$ females). Figure $6 \mathrm{~b}$ shows the interest in politics by age group (16-17-year-olds, 18-20-yearolds, 21-24-year-olds, and 25-29-year-olds). Notably, a larger proportion of 21-24-year-olds (19 $\%$ ) and 25-29-year-olds ( $22 \%$ ) show a high level of interest in politics compared to the younger age groups. Accordingly, the proportion of older age groups that show no interest in politics is smaller compared to younger age groups. The higher levels of interest in politics for older age groups may be related to the right to vote and individual changes in life situations. 
Figure 6: Level of political interest by gender (Panel A) and by age group (Panel B). YSL 2019

(a) Political Interest by Gender

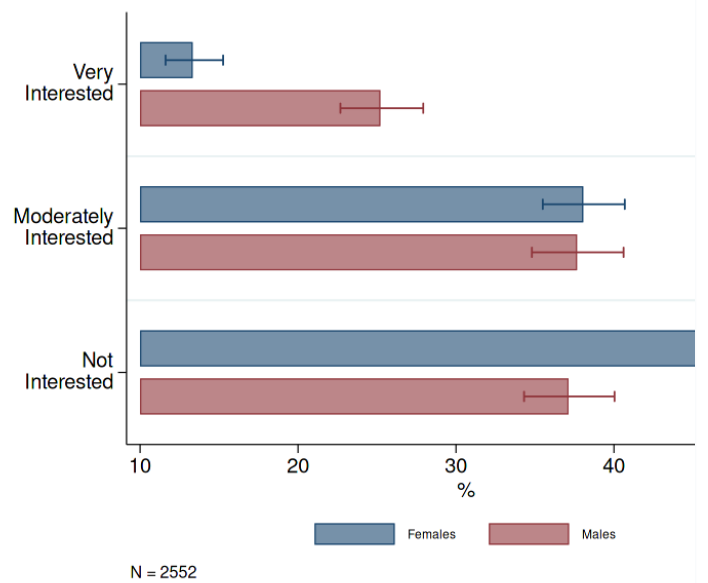

(b) Political Interest by Age

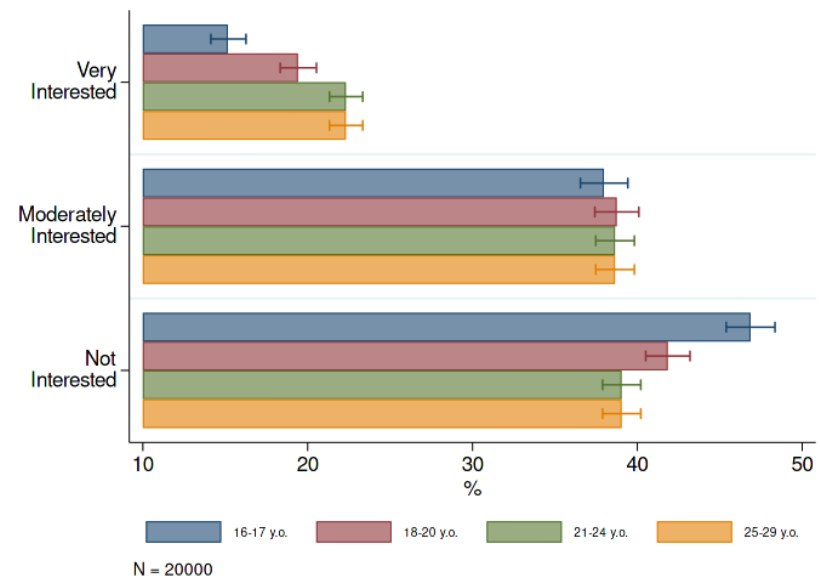

In the multivariate model including gender, age, migration background, and SES (measured both as subjective individual and family wealth), we find a negative and statistically significant effect of both SES variables. However, we do not find evidence of interaction effects between SES and migration background (see Annex).

Figure 7 shows the share of individuals participating in different types of political activities in the past. Among the actions with 'direct' participation, engaging in an authorised demonstration is the most reported activity by respondents. Among the activities with indirect involvement, boycotting goods and posting/sharing political contents online are the most reported political actions.

Figure 7: Types of political actions done in the past, in percent (YSL 2019)

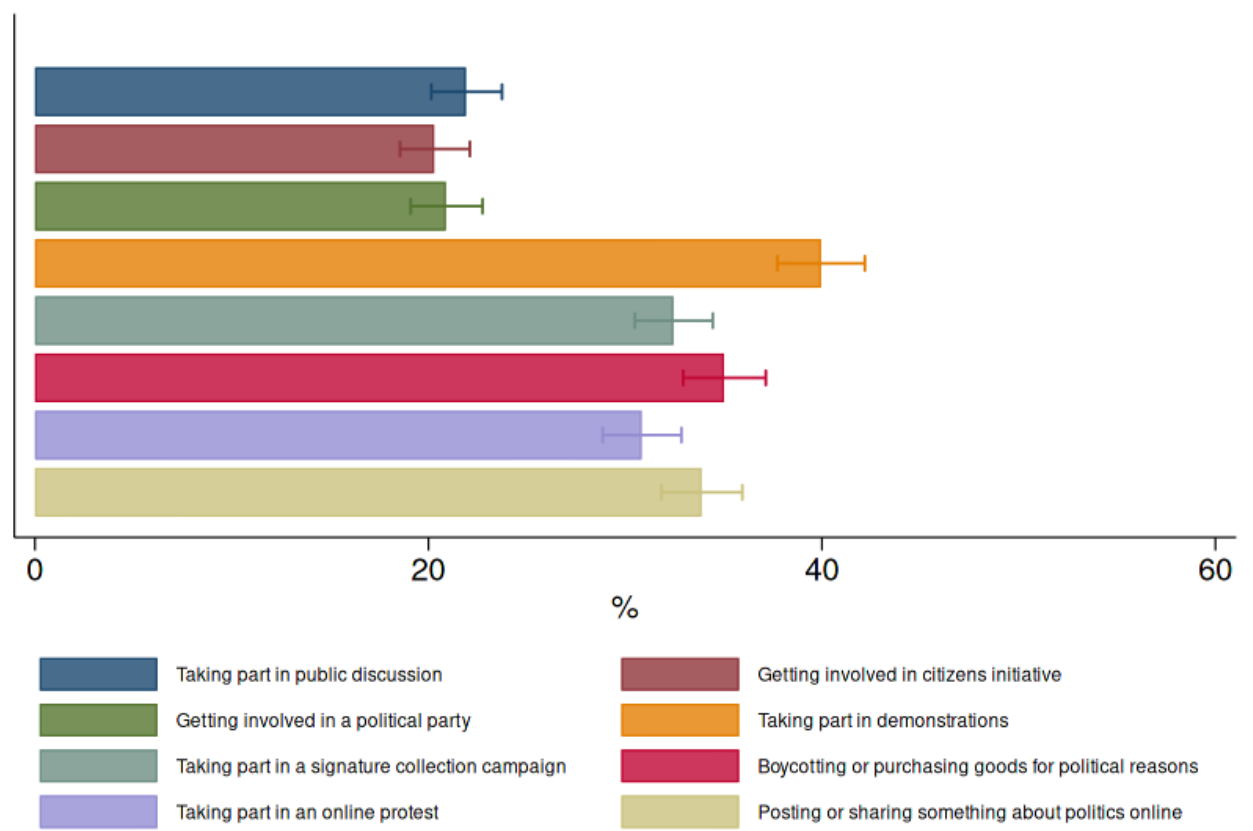

$\mathrm{N}=2091,2026,1954,1915,2191,2027,2092,2087$ 
Overall, 'indirect' means of political action (i.e., taking part in signature collection, boycotting/purchasing goods for political reasons, taking part in online protests and posting/sharing something about politics online) are the more common political actions taken by young people in Luxembourg compared to conventional forms of political engagement such as involvement in political parties or citizens' initiatives. Since Luxembourg is a superdiverse state, according to Vertovec's (2007) definition of superdiversity, this leads us to the question of the effect of superdiversity on political participation, especially among youths with increasingly complex biographies (Vertovec, 2007). Barrett and Pachi (2019) show that the levels of political engagement vary across different migration backgrounds or generations. Young people who have a (recent) immigration background tend to have low engagement. However, Barrett and Pachi (2019) point out that youth political engagement is rather complex and shows a diverse set of interactions between sociodemographic and socioeconomic factors such as migration background and gender. However, Osman et al. (2020) claim that adolescents with ethnoculturally diverse social networks are more likely to engage politically and even argue that diverse social networks and political behaviour reciprocally reinforce each other. Teney and Hanquinet (2012) study the interaction between social capital and political participation, and show that the two most politically active groups tend to have very few friends from another origin. The authors state that rather than engaging less than their native counterparts, migrants or ethnic minority groups turn toward distinct forms of political activism which may not be considered by conservative measurements of political participation.

Figure 8: Political actions done in the past by migration background (YSL 2019)
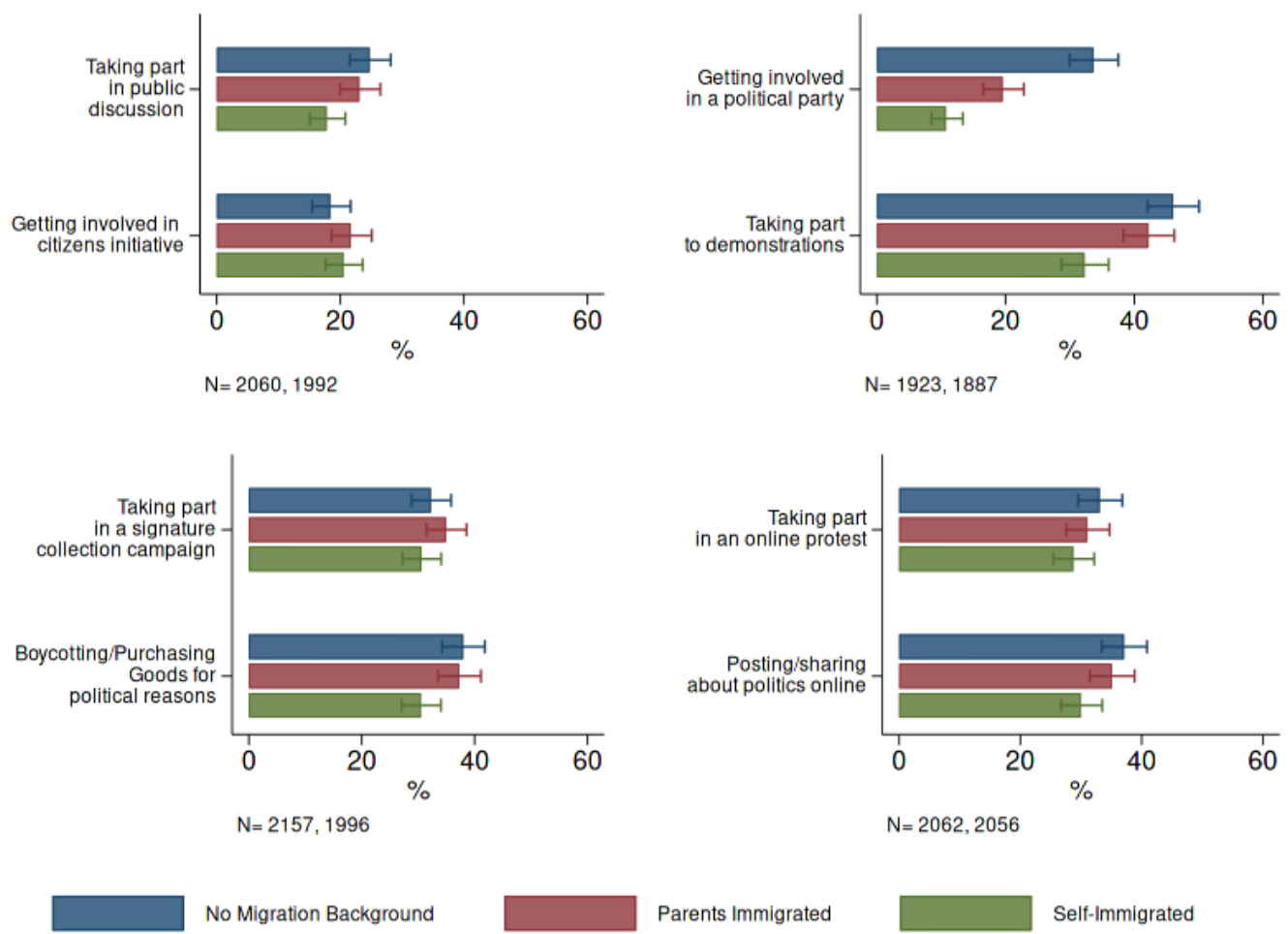

In Figure 8, we can see that participating in a political party (upper right panel) has been reported significantly more often by respondents with no migration background compared to respondents with a first- or second-generation migration background. We find similar results 
for participating in demonstrations. However, for demonstrations, only the self-immigrated respondents report having joined a protest in the past significantly less often than the other respondents. For other types of political participation, we do not find statistically significant differences between the respondent groups.

\section{The relationship between political interest and the different as- pects of national identity}

In the previous sections, we have focused on how individuals with different migration backgrounds evaluate the specific elements of national identity as important, and the levels of interest in politics and the type of political actions taken. In this section, we combine the two elements under study to further investigate potential associations between national identity and interest in politics. We aim to answer the following question: Is there an association between the level of interest in politics and considering a specific item of national identity as important? To answer this question, we first describe how the elements of national identity are considered important according to the levels of political interest. Subsequently, we calculate the probability of considering these specific items important, given the level of interest in politics. Lastly, we add the migration background of the young respondents to our analysis. Figure 9 is subdivided into five cross-tabulations, one for each element of national identity. The first subgraph (in the top-left part of Figure 9) shows how many young individuals ${ }^{1}$ consider 'being born in Luxembourg' as important, given their level of interest in politics (i.e., computing the percentages across the columns, here differently coloured for easing the interpretation). Our results show that individuals with a higher interest in politics less often consider 'being born in Luxembourg' as an important aspect to be a real Luxembourger (35\%) than individuals with no interest in politics $(52 \%)$. That is, for the ius soli element of national identity, the decrease of interest in politics corresponds to an increase of importance of this item among respondents.

\footnotetext{
${ }^{1}$ In percentage points.
} 
Figure 9: Cross-tabulation of levels of interest in politics (in columns) and importance of elements of national identity (in rows). Percentages are computed by column. Luxembourg, 2019 (YSL 2019)
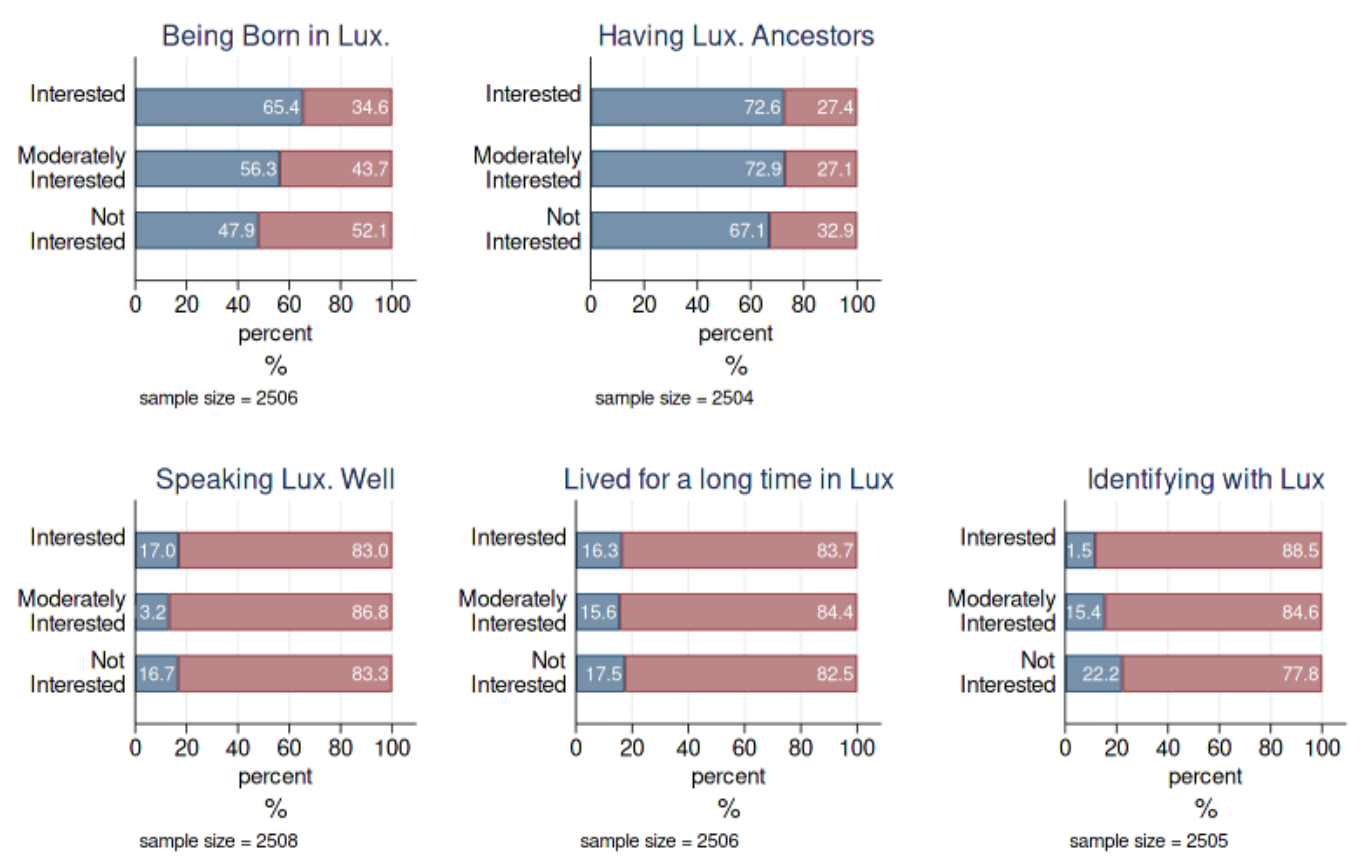

For the two socio-cultural elements of national identity (i.e., speaking Luxembourgish well and having lived for a long time in Luxembourg), the third and fourth sub-panels of Figure 9 (starting from the bottom-left) show no clear correspondence between the two. For 'identifying with Luxembourg', the results show that with a decrease of political interest of the young respondents, this national identity element is more often considered important. One question that drives our aim to deepen our understanding of these observed patterns is as follows: what are the probabilities, given the levels of interest in politics, that one individual would consider specific items of the concept of national identity important or not? We perform a logistic regression analysis to answer this question ${ }^{2}$ We calculate the probability of our respondents answering 'Important' to each given item of national identity according to their levels of political interest. In Figure 10, these probabilities are expressed in terms of contrasts, that is, we compare the probabilities of our respondents answering, 'Important' with a higher level of political interest (i.e., 'Very Interested' in the graph) versus respondents with lower interest, e.g., 'Moderately Interested' and 'Not Interested'.

\footnotetext{
${ }^{2}$ This statistical tool is specifically designed to assess the probability that one respondent will answer one outcome rather than another. Specifically, the statistical model compares the probability that one respondent answers 'yes' (or, in our case, 'Important') versus the probability that the respondent would answer 'no' (in our case, 'Not Important').
} 
Figure 10: Probability of answering 'Important' versus 'Not Important' to the items of national identity by levels of political interest (YSL 2019).
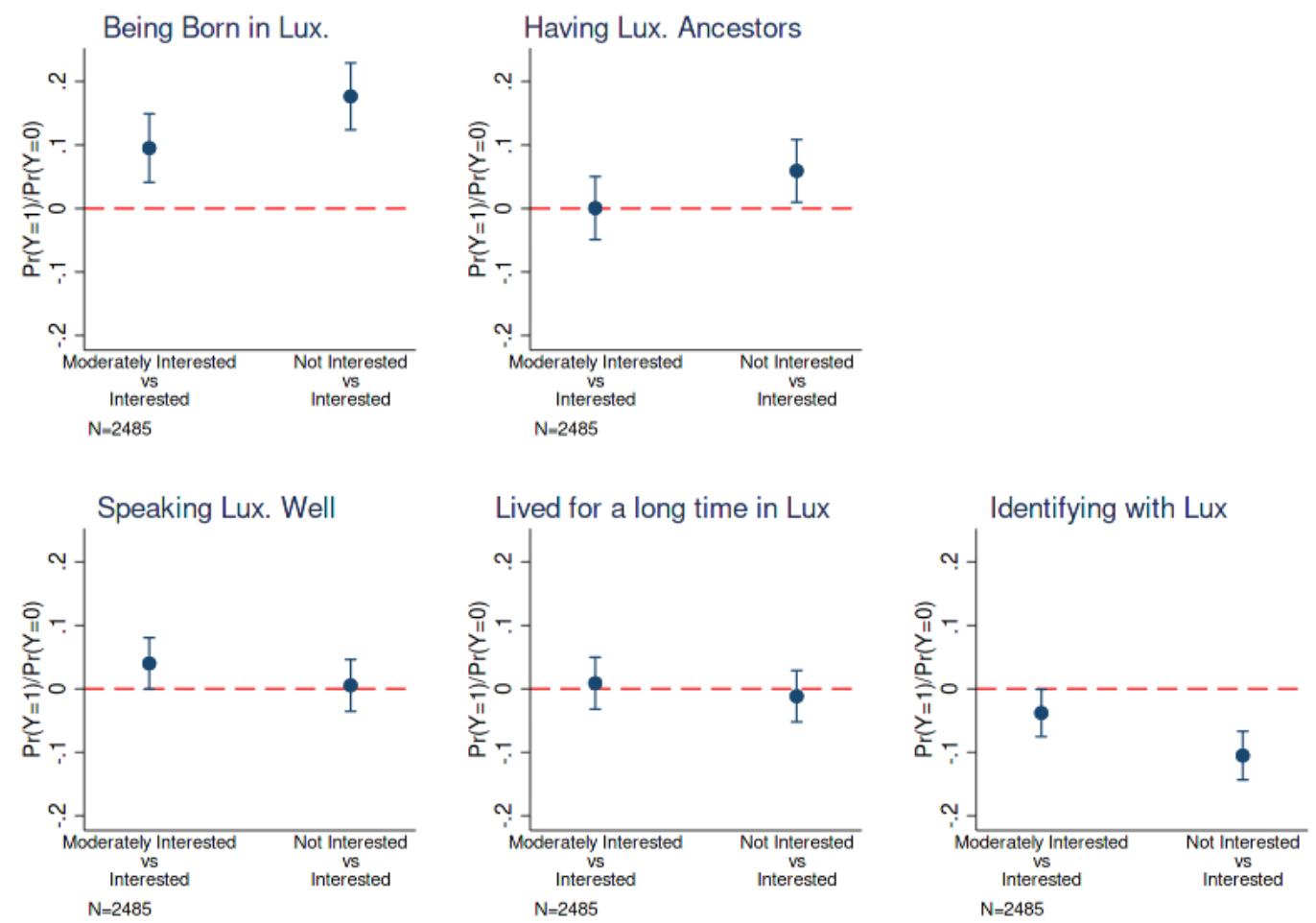

The points ${ }^{3}$ in the graph indicate the difference in probability to the answer 'Important' for each item of national identity considered in the analysis. As these are estimates from a statistical analysis, we also report the confidence intervals ${ }^{4}$. The red dashed line indicates non-significance of the differentials between these groups. In Figure 10, if the whiskers of the 95\% confidence intervals do not intersect with the red dashed line indicating the zero effect, the differences between levels of political interest in the probability of considering the national identity items as important is significant. Otherwise, the differences among individuals with different levels of political interest are not substantial enough to determine a clear distinction. For example, the top left panel shows the probability of deeming 'being born in Luxembourg' important when comparing respondents who are moderately interested in politics or not interested in politics with respondents who stated being (very) interested in politics. This means that as the respondents' interest in politics decreases (i.e., passing from 'interested' to 'moderately interested' or from 'interested' to 'not interested'), the probability of considering 'being born in Luxembourg' as an important element of national identity increases. For the panel devoted to the relationship between the importance of having Luxembourgish ancestors and interest in politics (e.g., in the upper row at middle position), the findings suggest that there is a substantial difference in the probability of considering the ius soli element of national identity as important only when comparing the individuals who are and are not interested in politics. This panel shows that individuals with no interest in politics are particularly more likely to consider the ius soli item as

\footnotetext{
${ }^{3}$ The points in the graphs are to be interpreted as the coefficients of the logistic regression. The scale on the y-axis is expressed in log of odds; that is, the odds computed by the statistical tool are converted to a log scale.

${ }^{4}$ The range of possible estimate values in which we are $95 \%$ confident that the real effect is in the population, represented by the whiskers that start from the point estimations.
} 
important compared to individuals who are interested in politics. Regarding the socio-cultural elements of national identity, the findings show that there are no substantial differences between individuals with different levels of political interest who deem the linguistic aspect of national identity (i.e., speaking Luxembourgish well, in the upper-right panel of Figure 10) and living for a long time in Luxembourg (in the bottom-left panel) as important. The panel in the bottom middle position of Figure 10 shows the findings for the relationship between the 'having lived in Lux for a long time' item of national identity and the level of political interest of the young respondents. This panel depicts a substantial difference between individuals with a strong interest in politics and those with no interest. That is, individuals with no interest in politics are less likely to consider this item as an important element of national identity, compared to individuals who are interested in politics.

\section{The role of migration background}

This section analyses national identity and political interest, with a focus on the migration background of the young respondents. Figure 11 shows the findings computed with the same statistical tool as in the previous section (The relationship between political interest and the different aspects of national identity), with the addition of migration background as an additional variable. The groups are composed as follows: Being a native Luxembourger and interested in politics is the reference category ${ }^{5}$. The comparison groups are being moderately interested and with parents immigrated, being moderately interested and self-immigrated, not being interested and with parents immigrated, not being interested, and self-immigrated.

\footnotetext{
${ }^{5}$ The group with which we compare all the others.
} 
Figure 11: Probability of answering 'Important' versus 'Not Important' to the items of national identity by levels of political interest (YSL 2019).
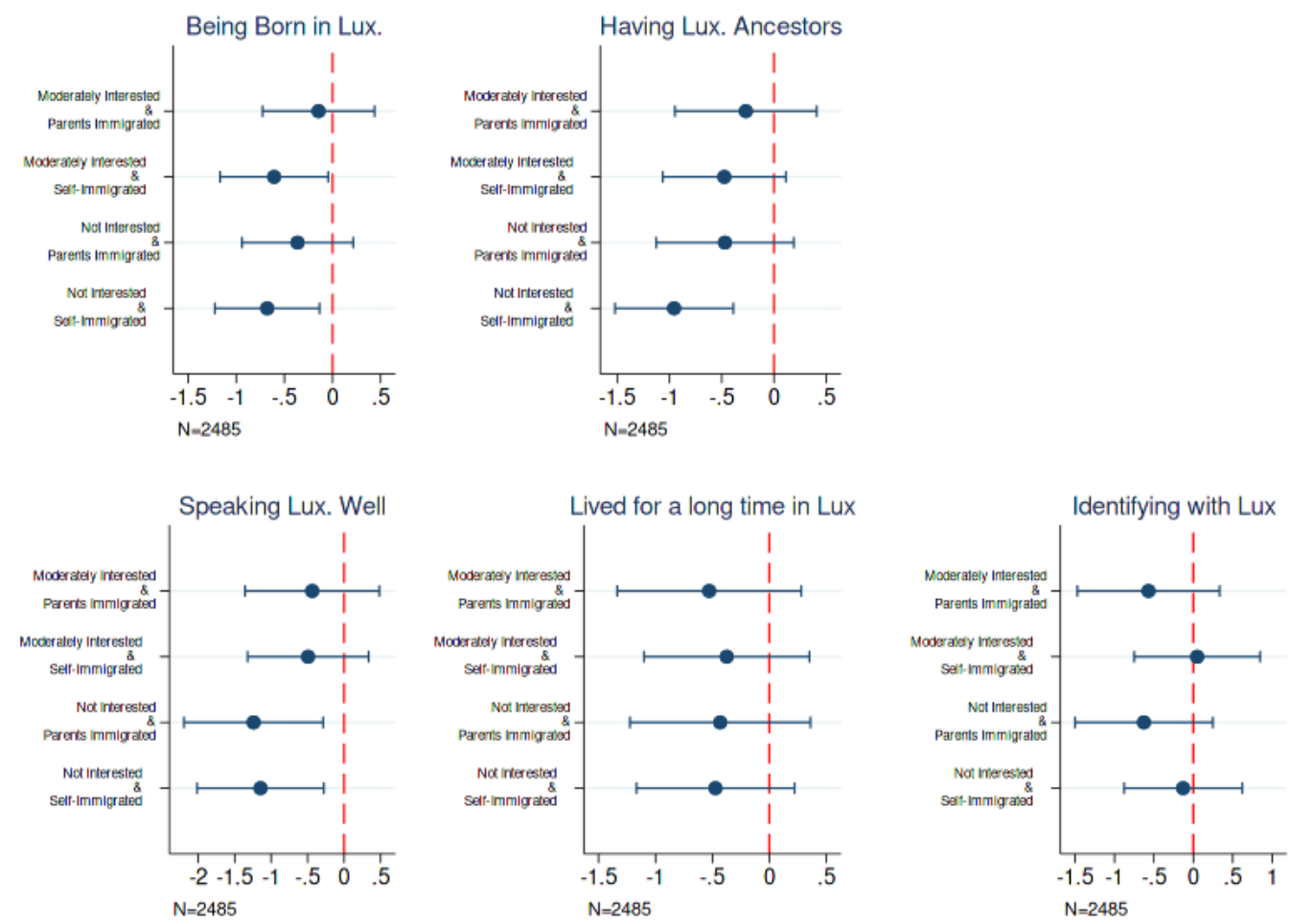

From the first panel (upper left panel) of Figure 11, the findings suggest that there is a substantial difference between individuals who are moderately interested in politics and selfimmigrated, compared with individuals who are interested and natives. The former group is less likely to consider the ius soli aspect of national identity as important. We can further identify a substantial difference between individuals who are not interested in politics and selfimmigrated. Compared to our reference category, this group is less likely to find 'being born in Luxembourg' as an important aspect of national identity. Focusing on the ius sanguinis aspect of national identity (upper middle panel of Figure 11), the only substantial difference can be found when comparing the reference group with individuals not interested in politics and selfimmigrated. More precisely, self-immigrated individuals that are not interested in politics are less likely to deem this aspect of national identity important compared with natives that are interested in politics. In the lower left panel of Figure 11, we see how the interest in politics and migration background shapes the probability of considering 'speaking Luxembourgish well' as an important aspect of national identity. The findings suggest that both individuals with a first- or second-generation migration background, and those who are disinterested in politics are less likely to consider the Luxembourgish language as an important item for national identity compared to the reference group. Lastly, we observe no substantial difference (either for interest in politics or for migration background) in considering 'living in Luxembourg for a long time' (bottom middle panel of Figure 11 and 'identifying with Luxembourg' (bottom right panel of Figure 11 as important elements for national identity. 


\section{Discussion}

We find that certain aspects of national identity are supported more than others across all groups of migration backgrounds. Young people in Luxembourg generally support the importance of sociocultural aspects of national identity more than the traditional aspects of national identity based on birthplace and ancestry. However, there are differences in the support for these items across respondents with different migration backgrounds. We can only assume that these differences are related to the individual experiences of our respondents while living (and growing up) in Luxembourg or their socialisation. In fact, we find some evidence of the effect of years spent in Luxembourg on the importance of ius soli (born in Luxembourg) and ius sanguinis (having Luxembourgish ancestors). Our results further show that migration background does affect the political interest of young people in Luxembourg. This finding is consistent with international studies on youth civic and political engagement (Amétépé and Hartmann-Hirsch, 2011; Barrett and Pachi, 2019; Rapp, 2020). Nonetheless, we need to differentiate between the first- and second-generation migration backgrounds. Furthermore, engagement in political actions is rather diverse for young people. International research on political participation shows that the presumption of the 'disengaging youth' needs to be taken with a pinch of salt since political participation should not only be measured by conventional forms of action. We show that traditional forms of political action, such as engagement in a political party, are mostly done by native Luxembourgers. Meanwhile, the more indirect forms of political participation, such as online protests or sharing political content online, are generally done more often and across all groups of young people. We further show that there is some interaction between the level of political interest, migration background, and the importance of national identity items. While individuals with no interest in politics are less likely to consider 'identifying oneself with Luxembourg' as an important element of national identity, they are more like to consider 'being born in Luxembourg' an important aspect compared to individuals who are interested in politics. When adding the aspect of migration background, we see that self-immigrated respondents with a moderate or no interest in politics deem the ius soli (born in Luxembourg) aspect as less important compared to the reference group of natives with a strong interest in politics. We also see that self-immigrated individuals with no interest in politics consider the ius sanguinis (having Luxembourgish ancestors) aspect as less important than the reference group. Lastly, the aspect of mastering the Luxembourgish language is deemed less important by both self-immigrated individuals and individuals whose parents immigrated to Luxembourg who are not interested in politics compared to the reference group. This shows us that neither the interest in politics or the migration background alone explains the differences in the valuation of national identity aspects. Rather, certain combinations of the two, as well as other aspects such as gender, SES, and age, do have explanatory power.

\section{Outlook - New ways of youth political engagement}

Stifterverband (2020) shows that the majority of young people in Germany felt less political efficacy during the Covid-19 pandemic. This points out how important the representation and communication of young people's needs are for their political engagement and trust, especially in times of crisis. Policymakers should consider this when trying to reach out to future generations, and not just in times of crisis. In their literature review on youth political participation in Europe, Galstyan (2019) explains that there are certain trends when it comes to the political engagement of young people in Europe. One of the main developments is a shift towards more engagement in unconventional forms of political participation and a disruption of boundaries 
between offline and online participation. We find evidence along these lines (see Figure 7 and 8). This notion is also supported by a wider body of research (Ekman and Amnå, 2012; Pollock and Hind, 2017; Villano and Bertocchi, 2014; White et al., 2000). Among some of these 'postmodern' (Forbrig, 2005) participation types of young people are digital, virtual, casual, and expressive and emotional ways of participating politically:

- clicktivism and slacktivism: voluntary or invitation-based clicks to express support for certain statements (e.g., online petitions);

- online campaigning: online platforms that invite users to start their own causes and gain support for them through their social networks (e.g., avaaz.org);

- crowdsourcing and crowdfunding: engaging a group or a 'crowd' to gain ideas, input, feedback, and financial support to transform ideas into reality;

- liquid democracy: online participation tools which allow collaborative decision-making by allowing each individual to vote directly or delegate their votes on issues to a chosen representative; and

- BarCamp: online conference system where programmes and sessions are developed by the participants themselves.

Galstyan (2019) and White et al. (2000) further describe that for many young people, political participation starts at the local or regional level where they can actually see the impact of their involvement. Youth work, therefore, becomes increasingly important as youth workers embody the link between young people and politics: 'youth workers play a role of [a] connector and translator, transferring information about political processes to young people, and also informing policy makers about young people's needs' (Galstyan 2019:7). Since the understanding of a political system and decision-making processes is central to tackling the declining trust in democracy and the political system in young people, the role of youth work and political education should not be underestimated. 


\section{Annex}

Table 1: Univariate Frequency Distributions of the Elements of National Identity

\begin{tabular}{|c|c|c|}
\hline & Count & Col \% \\
\hline \multicolumn{3}{|l|}{ Being Born in Lux. } \\
\hline Very important & 437 & 17.4 \\
\hline Important & 709 & 28.3 \\
\hline Neither & 596 & 23.8 \\
\hline Not important & 482 & 19.2 \\
\hline Not at all important & 282 & 11.3 \\
\hline Total & 2,506 & 100.0 \\
\hline \multicolumn{3}{|c|}{ Having Lux. Ancestors } \\
\hline Very important & 223 & 8.9 \\
\hline Important & 521 & 20.8 \\
\hline Neither & 697 & 27.8 \\
\hline Not important & 650 & 26.0 \\
\hline Not at all important & 413 & 16.5 \\
\hline Total & 2,504 & 100.0 \\
\hline \multicolumn{3}{|l|}{ Speaking Lux. Well } \\
\hline Very important & 1,323 & 52.8 \\
\hline Important & 799 & 31.9 \\
\hline Neither & 245 & 9.8 \\
\hline Not important & 79 & 3.1 \\
\hline Not at all important & 62 & 2.5 \\
\hline Total & 2,508 & 100.0 \\
\hline \multicolumn{3}{|c|}{ Lived for a long time in Lux } \\
\hline Very important & 1,037 & 41.4 \\
\hline Important & 1,054 & 42.1 \\
\hline Neither & 280 & 11.2 \\
\hline Not important & 75 & 3.0 \\
\hline Not at all important & 60 & 2.4 \\
\hline Total & 2,506 & 100.0 \\
\hline \multicolumn{3}{|l|}{ Identifying with Lux } \\
\hline Very important & 1,187 & 47.4 \\
\hline Important & 875 & 34.9 \\
\hline Neither & 310 & 12.4 \\
\hline Not important & 80 & 3.2 \\
\hline Not at all important & 53 & 2.1 \\
\hline Total & 2,505 & 100.0 \\
\hline
\end{tabular}


Table 2: Univariate Frequency Distributions of the Elements of National Identity by Migration Background

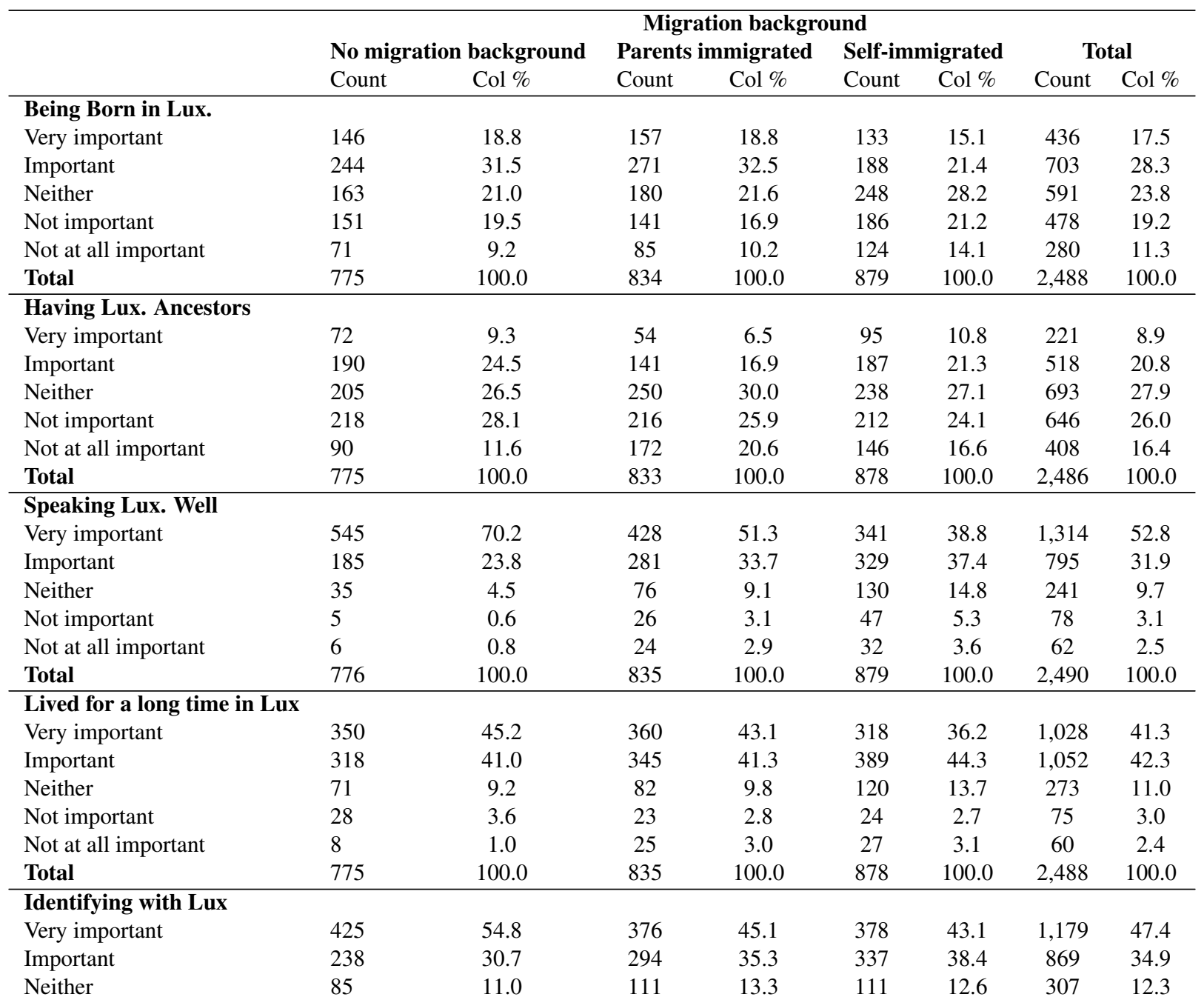




\begin{tabular}{|c|c|c|c|c|c|c|c|c|}
\hline Not important & 23 & 3.0 & 33 & 4.0 & 24 & 2.7 & 80 & 3.2 \\
\hline Not at all important & 4 & 0.5 & 20 & 2.4 & 28 & 3.2 & 52 & 2.1 \\
\hline Total & 775 & 100.0 & 834 & 100.0 & 878 & 100.0 & 2,487 & 100.0 \\
\hline \multicolumn{9}{|l|}{ Being Born in Lux. } \\
\hline Not Important & 385 & 49.7 & 406 & 48.7 & 558 & 63.5 & 1,349 & 54.2 \\
\hline Important & 390 & 50.3 & 428 & 51.3 & 321 & 36.5 & 1,139 & 45.8 \\
\hline Total & 775 & 100.0 & 834 & 100.0 & 879 & 100.0 & 2,488 & 100.0 \\
\hline \multicolumn{9}{|c|}{ Having Lux. Ancestors } \\
\hline Not Important & 513 & 66.2 & 638 & 76.6 & 596 & 67.9 & 1,747 & 70.3 \\
\hline Important & 262 & 33.8 & 195 & 23.4 & 282 & 32.1 & 739 & 29.7 \\
\hline Total & 775 & 100.0 & 833 & 100.0 & 878 & 100.0 & 2,486 & 100.0 \\
\hline \multicolumn{9}{|l|}{ Speaking Lux. Well } \\
\hline Not Important & 46 & 5.9 & 126 & 15.1 & 209 & 23.8 & 381 & 15.3 \\
\hline Important & 730 & 94.1 & 709 & 84.9 & 670 & 76.2 & 2,109 & 84.7 \\
\hline Total & 776 & 100.0 & 835 & 100.0 & 879 & 100.0 & 2,490 & 100.0 \\
\hline \multicolumn{9}{|c|}{ Lived for a long time in Lux } \\
\hline Not Important & 107 & 13.8 & 130 & 15.6 & 171 & 19.5 & 408 & 16.4 \\
\hline Important & 668 & 86.2 & 705 & 84.4 & 707 & 80.5 & 2,080 & 83.6 \\
\hline Total & 775 & 100.0 & 835 & 100.0 & 878 & 100.0 & 2,488 & 100.0 \\
\hline \multicolumn{9}{|l|}{ Identifying with Lux } \\
\hline Not Important & 112 & 14.5 & 164 & 19.7 & 163 & 18.6 & 439 & 17.7 \\
\hline Important & 663 & 85.5 & 670 & 80.3 & 715 & 81.4 & 2,048 & 82.3 \\
\hline Total & 775 & 100.0 & 834 & 100.0 & 878 & 100.0 & 2,487 & 100.0 \\
\hline
\end{tabular}


Table 3: Absolute and Percentage Frequency of the means of Political Participation

\begin{tabular}{|c|c|c|}
\hline & Count & $\%$ \\
\hline \multicolumn{3}{|c|}{ Taking part in public discussion } \\
\hline Done before & 458 & 21.9 \\
\hline Might do & 1,030 & 49.3 \\
\hline Never & 603 & 28.8 \\
\hline Total & 2,091 & 100.0 \\
\hline \multicolumn{3}{|c|}{ Getting involved in citizens initiative } \\
\hline Done before & 411 & 20.3 \\
\hline Might do & 1,203 & 59.4 \\
\hline Never & 412 & 20.3 \\
\hline Total & 2,026 & 100.0 \\
\hline \multicolumn{3}{|c|}{ Getting involved in a political party } \\
\hline Done before & 408 & 20.9 \\
\hline Might do & 729 & 37.3 \\
\hline Never & 817 & 41.8 \\
\hline Total & 1,954 & 100.0 \\
\hline \multicolumn{3}{|c|}{ Taking part in unauthorised demonstration } \\
\hline Done before & 417 & 21.1 \\
\hline Might do & 721 & 36.5 \\
\hline Never & 838 & 42.4 \\
\hline Total & 1,976 & 100.0 \\
\hline \multicolumn{3}{|c|}{ Taking part in authorised demonstration } \\
\hline Done before & 679 & 30.7 \\
\hline Might do & 922 & 41.7 \\
\hline Never & 608 & 27.5 \\
\hline Total & 2,209 & 100.0 \\
\hline \multicolumn{3}{|c|}{ Taking part in a signature collection campaign } \\
\hline Done before & 711 & 32.5 \\
\hline Might do & 810 & 37.0 \\
\hline Never & 670 & 30.6 \\
\hline Total & 2,191 & 100.0 \\
\hline \multicolumn{3}{|c|}{ Boycotting or purchasing goods for political reasons } \\
\hline Done before & 710 & 35.0 \\
\hline Might do & 584 & 28.8 \\
\hline Never & 733 & 36.2 \\
\hline Total & 2,027 & 100.0 \\
\hline \multicolumn{3}{|c|}{ Taking part in an online protest } \\
\hline Done before & 645 & 30.8 \\
\hline Might do & 774 & 37.0 \\
\hline Never & 673 & 32.2 \\
\hline Total & 2,092 & 100.0 \\
\hline \multicolumn{3}{|c|}{ Posting or sharing something about politics online } \\
\hline Done before & 707 & 33.9 \\
\hline Might do & 606 & 29.0 \\
\hline Never & 774 & 37.1 \\
\hline Total & 2,087 & 100.0 \\
\hline
\end{tabular}

Table 4: Univariate Distribution of the Interest in Politics

\begin{tabular}{lcc}
\hline Interest in politics & Count & Col \% \\
\hline Extremely & 111 & 4.3 \\
Very & 352 & 13.8 \\
Medium & 957 & 37.5 \\
Not very & 723 & 28.3 \\
Not at all & 409 & 16.0 \\
Total & 2,552 & 100.0 \\
\hline
\end{tabular}


Table 5: Absolute and Percentage Frequency of Political Interest relative to Migration Background

\begin{tabular}{llccccccc}
\hline \multirow{2}{*}{ Interest in politics } & \multicolumn{4}{c}{$\begin{array}{c}\text { No migration background } \\
\text { Count }\end{array}$} & $\%$ & \multicolumn{2}{c}{ Parents immigrated } & \multicolumn{2}{c}{ Self-immigrated } & \multicolumn{2}{c}{ Total } \\
& Count & $\%$ & Count & $\%$ & Count & $\%$ \\
\hline Extremely & 45 & 5.8 & 24 & 2.9 & 41 & 4.6 & 110 & 4.4 \\
Very & 117 & 15.0 & 95 & 11.3 & 137 & 15.4 & 349 & 13.9 \\
Medium & 300 & 38.5 & 342 & 40.8 & 299 & 33.7 & 941 & 37.5 \\
Not very & 220 & 28.2 & 243 & 29.0 & 243 & 27.4 & 706 & 28.2 \\
Not at all & 97 & 12.5 & 135 & 16.1 & 168 & 18.9 & 400 & 16.0 \\
Total & 779 & 100.0 & 839 & 100.0 & 888 & 100.0 & 2,506 & 100.0 \\
\hline
\end{tabular}


Table 6: Logistic Regression Model of elements of National Identity on SES (individual) Without Interaction Effects

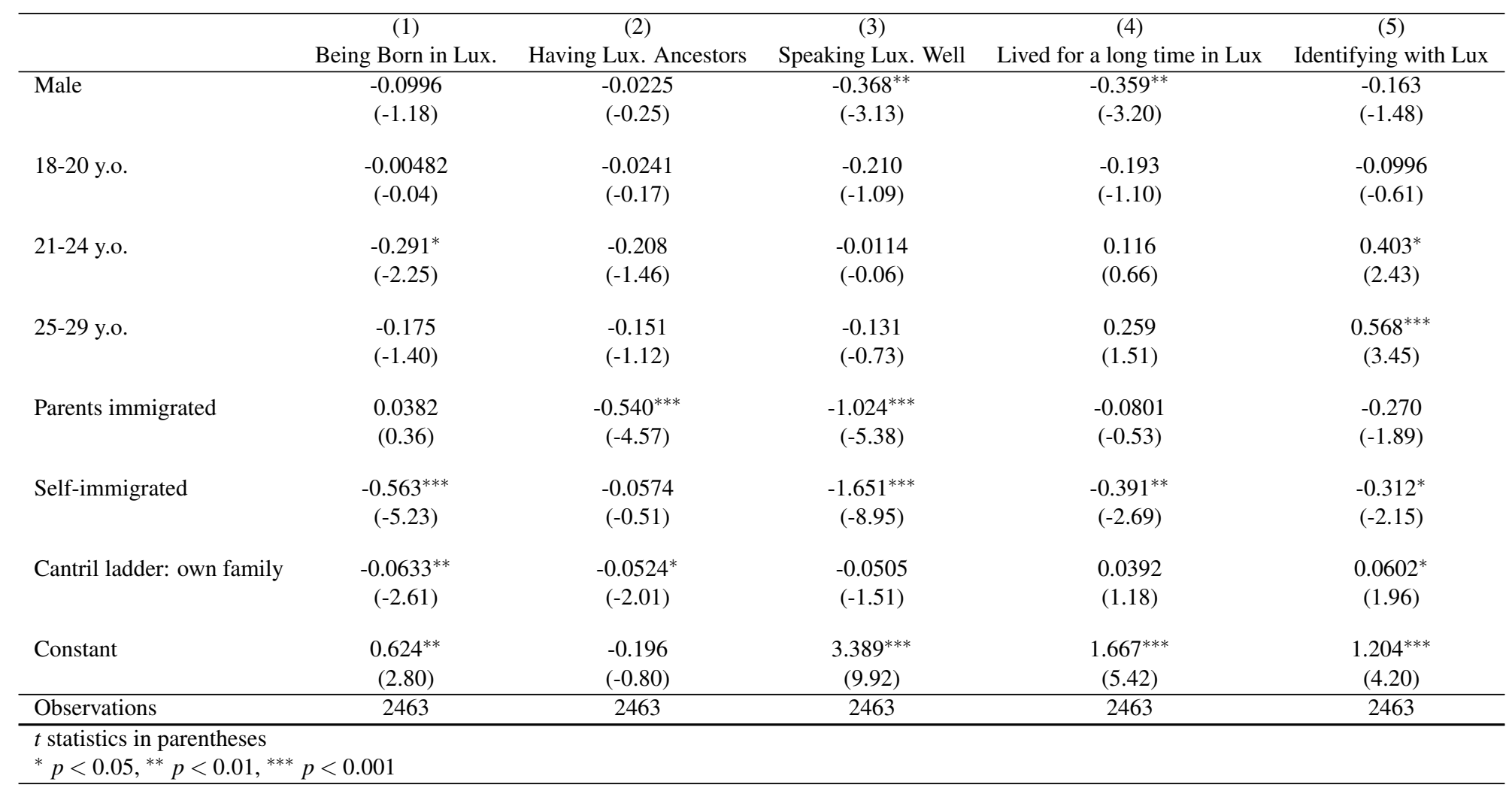

Table 7: Logistic Regression Model of elements of National Identity on SES (individual) With Interaction Effects

\begin{tabular}{|c|c|c|c|c|c|}
\hline & (1) & (2) & (3) & (4) & (5) \\
\hline Male & -0.102 & -0.0255 & $-0.368^{* *}$ & $-0.359^{* *}$ & -0.167 \\
\hline
\end{tabular}




\begin{tabular}{|c|c|c|c|c|c|}
\hline $18-20$ у.о. & $\begin{array}{c}0.00184 \\
(0.01)\end{array}$ & $\begin{array}{c}-0.0165 \\
(-0.11)\end{array}$ & $\begin{array}{l}-0.214 \\
(-1.11)\end{array}$ & $\begin{array}{l}-0.193 \\
(-1.10)\end{array}$ & $\begin{array}{c}-0.0880 \\
(-0.54)\end{array}$ \\
\hline $21-24$ y.o. & $\begin{array}{c}-0.285^{*} \\
(-2.20)\end{array}$ & $\begin{array}{l}-0.203 \\
(-1.43)\end{array}$ & $\begin{array}{c}-0.0144 \\
(-0.08)\end{array}$ & $\begin{array}{l}0.117 \\
(0.67)\end{array}$ & $\begin{array}{l}0.414^{*} \\
(2.49)\end{array}$ \\
\hline $25-29$ у.о. & $\begin{array}{l}-0.172 \\
(-1.37)\end{array}$ & $\begin{array}{l}-0.142 \\
(-1.06)\end{array}$ & $\begin{array}{l}-0.134 \\
(-0.75)\end{array}$ & $\begin{array}{l}0.258 \\
(1.50)\end{array}$ & $\begin{array}{c}0.574^{* * *} \\
(3.49)\end{array}$ \\
\hline Parents immigrated & $\begin{array}{l}-0.450 \\
(-1.00)\end{array}$ & $\begin{array}{c}-1.228^{*} \\
(-2.47)\end{array}$ & $\begin{array}{l}-0.519 \\
(-0.57)\end{array}$ & $\begin{array}{c}-0.0691 \\
(-0.10)\end{array}$ & $\begin{array}{c}-1.310^{*} \\
(-2.22)\end{array}$ \\
\hline Self-immigrated & $\begin{array}{l}-0.528 \\
(-1.27)\end{array}$ & $\begin{array}{c}-0.888^{*} \\
(-2.05)\end{array}$ & $\begin{array}{l}-1.196 \\
(-1.42)\end{array}$ & $\begin{array}{l}-0.191 \\
(-0.30)\end{array}$ & $\begin{array}{l}-0.471 \\
(-0.84)\end{array}$ \\
\hline Cantril ladder: own family & $\begin{array}{c}-0.0806 \\
(-1.71)\end{array}$ & $\begin{array}{c}-0.136^{* *} \\
(-2.69)\end{array}$ & $\begin{array}{c}0.00838 \\
(0.08)\end{array}$ & $\begin{array}{c}0.0549 \\
(0.71)\end{array}$ & $\begin{array}{c}0.00423 \\
(0.06)\end{array}$ \\
\hline Parents immigrated $\times$ Cantril ladder: own family & $\begin{array}{c}0.0734 \\
(1.15)\end{array}$ & $\begin{array}{c}0.0992 \\
(1.38)\end{array}$ & $\begin{array}{c}-0.0716 \\
(-0.57)\end{array}$ & $\begin{array}{c}-0.000293 \\
(-0.00)\end{array}$ & $\begin{array}{l}0.158 \\
(1.88)\end{array}$ \\
\hline Self-immigrated $\times$ Cantril ladder: own family & $\begin{array}{c}-0.00919 \\
(-0.15)\end{array}$ & $\begin{array}{c}0.124^{*} \\
(1.97)\end{array}$ & $\begin{array}{c}-0.0644 \\
(-0.55)\end{array}$ & $\begin{array}{c}-0.0308 \\
(-0.34)\end{array}$ & $\begin{array}{c}0.0164 \\
(0.21)\end{array}$ \\
\hline Constant & $\begin{array}{l}0.743^{*} \\
(2.05)\end{array}$ & $\begin{array}{l}0.390 \\
(1.02)\end{array}$ & $\begin{array}{c}2.970^{* * *} \\
(3.67)\end{array}$ & $\begin{array}{c}1.557^{* *} \\
(2.73)\end{array}$ & $\begin{array}{c}1.594^{* *} \\
(3.17)\end{array}$ \\
\hline Observations & 2463 & 2463 & 2463 & 2463 & 2463 \\
\hline $\begin{array}{l}t \text { statistics in parentheses } \\
{ }^{*} p<0.05,{ }^{* *} p<0.01,{ }^{* * *} p<0.001\end{array}$ & & & & & \\
\hline
\end{tabular}

Table 8: Logistic Regression Model of elements of National Identity on SES (own family) Without Interaction Effects

\begin{tabular}{|c|c|c|c|c|c|}
\hline & $(1)$ & $(2)$ & $(3)$ & (4) & (5) \\
\hline & Being Born in Lux. & Having Lux. Ancestors & Speaking Lux. Well & Lived for a long time in Lux & Identifying with Lux \\
\hline Male & $\begin{array}{l}-0.108 \\
(-1.28)\end{array}$ & $\begin{array}{l}-0.0297 \\
(-0.32)\end{array}$ & $\begin{array}{c}-0.357^{* *} \\
(-3.01)\end{array}$ & $\begin{array}{r}-0.345^{* *} \\
(-3.07)\end{array}$ & $\begin{array}{l}-0.144 \\
(-1.31)\end{array}$ \\
\hline $18-20$ у.о. & 0.00177 & -0.0191 & -0.181 & -0.188 & -0.0954 \\
\hline
\end{tabular}




\begin{tabular}{|c|c|c|c|c|c|}
\hline & $(0.01)$ & $(-0.13)$ & $(-0.94)$ & $(-1.07)$ & $(-0.59)$ \\
\hline 21-24 у.о. & $\begin{array}{l}-0.296^{*} \\
(-2.29)\end{array}$ & $\begin{array}{l}-0.212 \\
(-1.49)\end{array}$ & $\begin{array}{c}0.0329 \\
(0.17)\end{array}$ & $\begin{array}{l}0.143 \\
(0.82)\end{array}$ & $\begin{array}{c}0.438^{* *} \\
(2.63)\end{array}$ \\
\hline $25-29$ у.о. & $\begin{array}{l}-0.172 \\
(-1.37)\end{array}$ & $\begin{array}{l}-0.148 \\
(-1.10)\end{array}$ & $\begin{array}{l}-0.0957 \\
(-0.53)\end{array}$ & $\begin{array}{l}0.270 \\
(1.57)\end{array}$ & $\begin{array}{c}0.580^{* * *} \\
(3.52)\end{array}$ \\
\hline Parents immigrated & $\begin{array}{c}0.0588 \\
(0.56)\end{array}$ & $\begin{array}{c}-0.522^{* * *} \\
(-4.46)\end{array}$ & $\begin{array}{c}-0.982^{* * *} \\
(-5.20)\end{array}$ & $\begin{array}{c}-0.0798 \\
(-0.53)\end{array}$ & $\begin{array}{l}-0.273 \\
(-1.90)\end{array}$ \\
\hline Self-immigrated & $\begin{array}{c}-0.533^{* * *} \\
(-5.04)\end{array}$ & $\begin{array}{c}-0.0321 \\
(-0.29)\end{array}$ & $\begin{array}{c}-1.576^{* * *} \\
(-8.69)\end{array}$ & $\begin{array}{c}-0.382^{* *} \\
(-2.69)\end{array}$ & $\begin{array}{c}-0.305^{*} \\
(-2.14)\end{array}$ \\
\hline Cantril ladder: own life & $\begin{array}{c}-0.0614^{*} \\
(-2.42)\end{array}$ & $\begin{array}{c}-0.0501 \\
(-1.82)\end{array}$ & $\begin{array}{c}0.0322 \\
(0.95)\end{array}$ & $\begin{array}{c}0.0785^{*} \\
(2.37)\end{array}$ & $\begin{array}{c}0.109^{* * *} \\
(3.45)\end{array}$ \\
\hline Constant & $\begin{array}{c}0.609^{* *} \\
(2.67)\end{array}$ & $\begin{array}{l}-0.213 \\
(-0.85)\end{array}$ & $\begin{array}{c}2.763^{* * *} \\
(8.09)\end{array}$ & $\begin{array}{c}1.375^{* * *} \\
(4.54)\end{array}$ & $\begin{array}{c}0.842^{* *} \\
(2.92)\end{array}$ \\
\hline Observations & 2463 & 2463 & 2463 & 2463 & 2463 \\
\hline
\end{tabular}

Table 9: Logistic Regression Model of elements of National Identity on SES (own family) With Interaction Effects

\begin{tabular}{|c|c|c|c|c|c|}
\hline & $\begin{array}{c}\text { (1) } \\
\text { Being Born in Lux. }\end{array}$ & $\begin{array}{c}\text { (2) } \\
\text { Having Lux. Ancestors }\end{array}$ & $\begin{array}{c}\text { (3) } \\
\text { Speaking Lux. Well }\end{array}$ & $\begin{array}{c}\text { (4) } \\
\text { Lived for a long time in Lux }\end{array}$ & $\begin{array}{c}\text { (5) } \\
\text { Identifying with Lux }\end{array}$ \\
\hline Male & $\begin{array}{l}-0.109 \\
(-1.29)\end{array}$ & $\begin{array}{c}-0.0294 \\
(-0.32)\end{array}$ & $\begin{array}{c}-0.360^{* *} \\
(-3.04)\end{array}$ & $\begin{array}{c}-0.342^{* *} \\
(-3.03)\end{array}$ & $\begin{array}{l}-0.140 \\
(-1.26)\end{array}$ \\
\hline $18-20$ у.о. & $\begin{array}{c}-0.00383 \\
(-0.03)\end{array}$ & $\begin{array}{c}-0.0229 \\
(-0.16)\end{array}$ & $\begin{array}{l}-0.181 \\
(-0.94)\end{array}$ & $\begin{array}{l}-0.188 \\
(-1.07)\end{array}$ & $\begin{array}{l}-0.101 \\
(-0.62)\end{array}$ \\
\hline 21-24 у.о. & $\begin{array}{l}-0.297^{*} \\
(-2.28)\end{array}$ & $\begin{array}{l}-0.213 \\
(-1.50)\end{array}$ & $\begin{array}{c}0.0371 \\
(0.19)\end{array}$ & $\begin{array}{l}0.140 \\
(0.80)\end{array}$ & $\begin{array}{l}0.432^{* *} \\
(2.60)\end{array}$ \\
\hline 25-29 у.о. & $\begin{array}{l}-0.180 \\
(-1.43)\end{array}$ & $\begin{array}{l}-0.153 \\
(-1.14)\end{array}$ & $\begin{array}{l}-0.0925 \\
(-0.51)\end{array}$ & $\begin{array}{l}0.267 \\
(1.55)\end{array}$ & $\begin{array}{c}0.570^{* * *} \\
(3.46)\end{array}$ \\
\hline
\end{tabular}




\begin{tabular}{|c|c|c|c|c|c|}
\hline Parents immigrated & $\begin{array}{l}-0.678 \\
(-1.46)\end{array}$ & $\begin{array}{l}-0.914 \\
(-1.77)\end{array}$ & $\begin{array}{l}-1.058 \\
(-1.18)\end{array}$ & $\begin{array}{c}-0.0391 \\
(-0.06)\end{array}$ & $\begin{array}{l}-0.693 \\
(-1.13)\end{array}$ \\
\hline Self-immigrated & $\begin{array}{l}-1.121^{*} \\
(-2.52)\end{array}$ & $\begin{array}{l}-0.410 \\
(-0.89)\end{array}$ & $\begin{array}{l}-1.339 \\
(-1.56)\end{array}$ & $\begin{array}{l}-0.641 \\
(-1.10)\end{array}$ & $\begin{array}{r}-1.142^{*} \\
(-2.01)\end{array}$ \\
\hline Cantril ladder: own life & $\begin{array}{c}-0.130^{* *} \\
(-2.67)\end{array}$ & $\begin{array}{c}-0.0901 \\
(-1.75)\end{array}$ & $\begin{array}{c}0.0490 \\
(0.43)\end{array}$ & $\begin{array}{c}0.0621 \\
(0.92)\end{array}$ & $\begin{array}{c}0.0340 \\
(0.51)\end{array}$ \\
\hline Parents immigrated $\times$ Cantril ladder: own life & $\begin{array}{l}0.106 \\
(1.63)\end{array}$ & $\begin{array}{l}0.0565 \\
(0.77)\end{array}$ & $\begin{array}{l}0.0122 \\
(0.10)\end{array}$ & $\begin{array}{c}-0.00693 \\
(-0.08)\end{array}$ & $\begin{array}{c}0.0595 \\
(0.69)\end{array}$ \\
\hline Self-immigrated $\times$ Cantril ladder: own life & $\begin{array}{c}0.0850 \\
(1.34)\end{array}$ & $\begin{array}{l}0.0554 \\
(0.84)\end{array}$ & $\begin{array}{c}-0.0357 \\
(-0.29)\end{array}$ & $\begin{array}{r}0.0397 \\
(0.48)\end{array}$ & $\begin{array}{l}0.126 \\
(1.54)\end{array}$ \\
\hline Constant & $\begin{array}{c}1.100^{* *} \\
(2.92) \\
\end{array}$ & $\begin{array}{c}0.0705 \\
(0.18) \\
\end{array}$ & $\begin{array}{c}2.645^{* *} \\
(3.19) \\
\end{array}$ & $\begin{array}{c}1.490^{* *} \\
(2.90) \\
\end{array}$ & $\begin{array}{c}1.370^{* *} \\
(2.68)\end{array}$ \\
\hline Observations & 2463 & 2463 & 2463 & 2463 & 2463 \\
\hline
\end{tabular}




\section{References}

Amétépé, F. and Hartmann-Hirsch, C. (2011). An outstanding positioning of migrants and nationals: The case of luxembourg. Population Review, 50(1):195-217.

Barrett, M. D. and Pachi, D. (2019). Youth civic and political engagement. Adolescence and society. Routledge, London, 1st edition.

Brady, H. E., Verba, S., and Schlozman, K. L. (1995). Beyond ses: A resource model of political participation. American Political Science Review, 89(2):271-294.

Canan, C. and Simon, M. K. (2018). Immigration, diversity and the relevance of ascriptive characteristics in defining national identity across 21 countries and 28 west-german districts. Migration Studies, 7(2):201-219.

Dumbrava, C. and Bauböck, R. (2015a). Bloodlines and belonging: Time to abandon ius sanguinis?

Dumbrava, C. and Bauböck, R. (2015b). Bloodlines and belonging: Time to abandon ius sanguinis?

Ekman, J. and Amnå, E. (2012). Political participation and civic engagement: Towards a new typology. Human Affairs, 22(3).

European Values Study (2016). European values study 2008: Integrated dataset (evs 2008).

Forbrig, J. (2005). Revisiting youth political participation: Challenges for research and democratic practice in Europe. Council of Europe, Strasbourg.

Gallego, A. (2007). Unequal political participation in europe. International Journal of Sociology, 37(4):10-25.

Galstyan, M. (2019). Youth political participation: Literature review.

Kitanova, M. (2020). Youth political participation in the eu: evidence from a cross-national analysis. Journal of Youth Studies, 23(7):819-836.

McLaren, L. (2017). Immigration, national identity and political trust in european democracies. Journal of Ethnic and Migration Studies, 43(3):379-399.

Ministère de l'Éducation nationale, de l'Enfance et de la Jeunesse and Université du Luxembourg (2015). Rapport national sur la situation de la jeunesse au luxembourg 2015: La transition de l'adolescence vers l'âge adulte.

Murdock, E. (2012). National identity: integrity and diversity in contemporary europe: The construal of national identities within the luxembourg context. Ethnicity Ethnic Minorities and Migrants, 2(7):70-85.

Osman, M., Miranda, D., and Jourde, C. (2020). Youth political engagement in adolescence. Canadian Psychology, 61(1):1-21.

Pollock, G. and Hind, E. (2017). Young people, contemporary challenges and the future trends.

Rapp, C. (2020). National attachments and the immigrant participation gap. Journal of Ethnic and Migration Studies, 46(13):2818-2840.

Schlozman, K. L., Burns, N., and Verba, S. (1994). Gender and the pathways to participation: The role of resources. The Journal of Politics, 56(4):963-990.

Skocpol, T. and Fiorina, M. P. (1999). Civic Engagement in American Democracy. Brookings Institution Press, Washington, United States.

Sozio, M. E., Procopio, A., and Samuel, R. (2020). Youth survey luxembourg: Technical report 2019.

STATEC (2020a). Luxembourg in figures: 2020.

STATEC (2020b). Population par sexe et par nationalité au 1er janvier 1981, 1991, 2001 - 2020.

STATEC (2021). Population luxembourgeoise et étrangère par âge et sexe au 1er janvier 2008 2020.

Stifterverband (2020). Ergebnisse der jugendumfrage: Deine stimme zur corona-stimmung. 
Teney, C. and Hanquinet, L. (2012). High political participation, high social capital? a relational analysis of youth social capital and political participation. Social Science Research, 41(5):1213-1226.

Umaña-Taylor, A. J., Kornienko, O., McDermott, E. R., and Motti-Stefanidi, F. (2020). National identity development and friendship network dynamics among immigrant and nonimmigrant youth. Journal of Youth and Adolescence, 49:706-723.

Vertovec, S. (2007). Super-diversity and its implications. Ethnic and Racial Studies, 30(6):1024-1054.

Villano, P. and Bertocchi, A. (2014). On active citizenship: Discourses and language about youth and migrants in italy. Journal of Civil Society, 10(1):82-99.

Vink, M. P. and de Groot, G.-R. (2010). Citizenship attribution in western europe: International framework and domestic trends. Journal of Ethnic and Migration Studies, 36(5):713-734.

White, C., Bruce, S., and Ritchie, J. (2000). Young people's politics: Political interest and engagement amongst 14-24 year olds.

Zani, B. and Barrett, M. (2012). Engaged citizens? political participation and social engagement among youth, women, minorities, and migrants. Human Affairs, 22(3). 